\title{
27 \\ Phosphates and bones: An analysis of the courtyard of marae Manunu, Huahine, Society Islands, French Polynesia
}

\author{
Paul Wallin \\ Department of Archaeology and Osteology, Gotland University, Sweden \\ Paul.Wallin@hgo.se \\ Inger Österholm \\ Department of Archaeology and Osteology, Gotland University, Sweden
}

Sven Österholm

Gotland Community College, Sweden

Reidar Solsvik

Kon-Tiki Museum, Oslo, Norway

\section{Introduction}

The investigations at marae Manunu (Figure 1) were part of an archaeological project called 'Local development and regional interactions', a collaboration between the Kon-Tiki Museum, B.P. Bishop Museum, Oslo University, and the Service de la Culture et du Patrimoine, Tahiti, French Polynesia. The project was conducted from 2001 to 2004 on the island of Huahine in the Society Islands. One team from the B.P. Bishop Museum in Hawai'i, led by Dr Y.H. Sinoto and E. Komori, investigated a submerged coastal habitation site on the base of the slope of Mata'ire'a hill behind Maeva Village. Another team from the Kon-Tiki Museum, led by the first author, investigated marae sites around Maeva village, as well as several other marae on the island.

The excavation of the marae Manunu took place in August 2003 and has been reported in detail elsewhere (Wallin et al. 2004; Wallin and Solsvik 2005a, b, 2006a, b). In this paper, we report the results of a phosphate analysis made in the courtyard of marae Manunu and along the ahu wall. The purpose of the study was to see whether ritual activity at marae, such as animal 


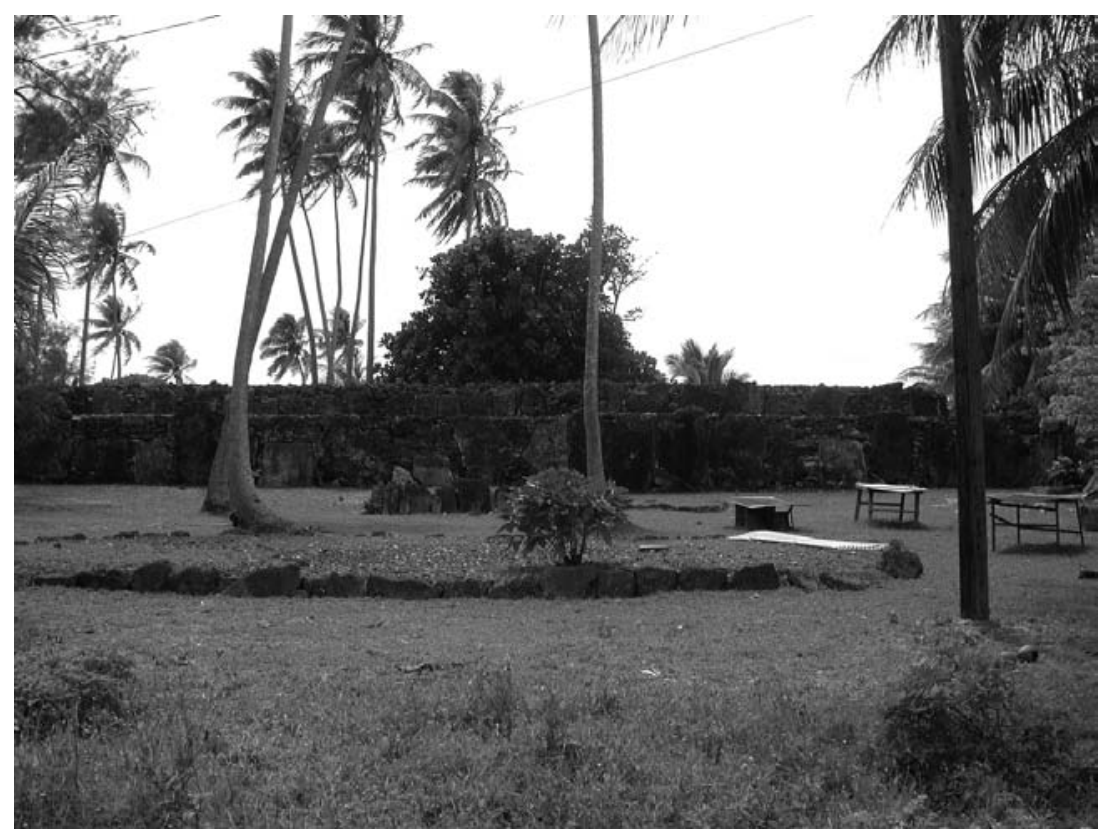

Figure 1. Front view of marae Manunu, Huahine (photo by Paul Wallin).

and human sacrifice, feasting and the presentation of food stuffs to deities, left behind phosphate residues. Areas with high and low phosphate were excavated to see whether archaeological data, particularly the amount of bone remains, correlated with the phosphate readings.

\section{The setting}

The district of Maeva comprises the north and northeastern part of Huahine Nui that surrounds the sacred mountain of Moua Tapu. A small village is on a strip of land along the lagoon and just behind the Maeva village, the hill of Mata'ire'a rises steeply to about $60 \mathrm{~m}$ above sea level. Along the slopes and on top of this hill, there are house foundations, terraces and about 40 marae structures. The most important temple on the island is marae Mata'ire'a Rahi, on the summit of Mata'ire'a. Across the lagoon from Maeva village on Motu Ovarei is the huge marae of Manunu-i-te-ra'i.

The settlement at Maeva consists of three distinct components. First, there are the 10 marae structures built along the shores of the lagoon-lake Fauna Nui that provided a range of marine foods in prehistory. These marae are the classic Leeward Island coastal marae type and comprised the ritual and ceremonial centre of Huahine during the proto-historic period. The most important of these marae, Orohahaa, is located in the grounds of the local church and has been destroyed. In conjunction with, and close to, these temples are large concave stone platforms with round-ended house curbing, located along the inland side of the modern road. Given the size and number of these house platforms, they probably represent chiefly dwelling platforms belonging to the late proto-historic era.

The settlement on the slopes and top of Mataire'a hill makes up the second component of the chiefly centre of Maeva. Test-excavation of house foundations in the upper parts of the Te Ana land division by Sinoto and Komori (Sinoto 1996) showed that settlement in this part of Mata'ire'a was underway by AD 1300-1400. Our investigations of marae structures on this same land division found, in several cases, evidence of habitation stratigraphically below marae platforms.

The third element of settlement at Maeva are the two marae structures which have islandwide religious significance; marae Mata'ire'a Rahi and marae Manunu. These two temples were 
of paramount importance in the ritual cycle of Huahine. Without them, a new paramount chief could not be invested in his position, nor could the life-giving pa'i atua ceremony take place. Marae Mata'ire'a Rahi is on the summit of the hill and marae Manunu has its ahu rear wall oriented towards the open sea. At these two marae all the ritual ceremonies necessary for annual growth and the maintenance of order were held. As part of the ritual cycle, the god Tane was carried from one marae to the next as the ritual calendar dictated.

A detailed settlement history for Mata'ire'a hill has not yet been proposed. Sinoto (1996) suggested the main settlement on the hill, inland from marae Tefano, marae Mata'ire'a Rahi and marae Tamata Uporu, was not in use during the proto-historic period. It was suggested that Mata'ire'a had been abandoned in favour of the settlement on the coastal flat close to the marae along the edge of the lagoon. Sinoto's argument was based on a morphological change in marae architecture from an 'Inland Type 2' to the classic 'Coastal Type' (Sinoto 1996:549-550, 2002). The marae seaward of marae Tefano (marae Mata'ire'a Rahi and marae Temata Uporu) had been rebuilt as the classic 'Coastal Type'. During our resurvey and excavation of marae Mata'ire'a Rahi, it became evident that the marae had been rebuilt from a Leeward Coastal Type to an Intermediate Type (Wallin et al. 2004; Wallin and Solsvik 2005a). The consequence of this rebuilding for the settlement sequence of Mata'ire'a remains to be determined. At present we know that: (1) settlements without marae were established on Mata'ire'a around AD 1300-1400; (2) sometime after AD 1450-1500 marae were constructed within these settlements; and (3) some of these settlements were in use up to historic times c. AD 1817.

\section{The two national marae of Maeva}

According to the missionary Orsmond, marae Manunu was the national temple of Huahine Nui and dedicated to the god Tane (Henry 1928). Tane was also the god honoured on marae Mata'ire'a Rahi and here the god had his earthly home in a small house built on stilts on a terrace just north of the great marae. That the abode of Tane was on marae Mata'ire'a Rahi and not on marae Manunu, might be interpreted to mean that Manunu was subordinate to Mata'ire'a Rahi in the religious hierarchy of Maeva. It is possible there existed a third temple, marae Orohahaa, in this ritual hierarchy that encompassed these two great temples.

\section{Investigations at marae Manunu}

Marae Manunu was restored by Y.H. Sinoto in 1967 and has been repaired several times since. The gigantic size of the ahu made it difficult from a practical perspective to excavate inside and underneath the ahu. We decided to concentrate our efforts, therefore, on the courtyard in front of the ahu. A local coordinate system was established in front of the ahu and c. $10 \mathrm{~m}$ right of the northwest corner of the ahu. Nine test units were excavated along three transect lines, spaced $10 \mathrm{~m}$ apart in the direction ENE and WSW. The units were excavated in $10 \mathrm{~cm}$ spits down to a well-defined sterile sand layer, usually reached at a depth of $20 \mathrm{~cm}$ to $30 \mathrm{~cm}$ below surface, after which the NW half of each unit was taken down with a shovel to 50-75 cm depth. After establishing the general stratigraphy, three areas containing bones were extended into area excavations. From these excavations we recovered 379 pieces of bone and charcoal, along with a piece of iron and a blue glass bead. The last two items may have been obtained from early European contacts.

\section{Radiocarbon dating marae Manunu}

Marae Manunu appears to have become the new ritual centre of Maeva after marae Mata'ire'a Rahi lost its importance. We wanted to see whether the transition in marae use that was attested 
in oral traditions could be identified by radiocarbon dating marae Manunu. Two samples, both on fragments of pig bone, have been analysed to date marae Manunu at the Waikato Laboratory in New Zealand. The first age result (Wk-14603) was on a fragment of pig jaw (Figure 2) found at a depth of about $35 \mathrm{~cm}$ on top of sterile beach sand and stratigraphically below a standing slab forming the ahu front wall (Wallin et al. 2004:76-83; Wallin and Solsvik 2005a). The bone sample gave a conventional radiocarbon age (CRA) of $306 \pm 42 \mathrm{BP}$ (Wk-14603, ${ }^{13} \mathrm{C}-$ $18.8 \pm 0.2 \%$ o). Another piece of pig bone was found under a slab of the ahu rear wall (Wallin et al. 2004), where it was probably deposited just before the wall slab was erected. This sample returned an age of $296 \pm 34 \mathrm{BP}$ (Wk-16790, ${ }^{13} \mathrm{C}-17.3 \pm 0.2$ ). Both of these dates when calibrated have a two-sigma span of $\mathrm{AD} 1650$ to 1950 . We conclude that the construction of marae Manunu occurred sometime after AD 1650 and probably well before European discovery of Tahiti in the 18th century.

\section{Phosphate analysis}

We systematically collected earth samples during excavations to test the feasibility of phosphate analysis for investigating ritual practices at Polynesian temple sites (Figure 3 and Figure 4). The aim was to identify locations which had detectable phosphate levels that might be the result of prehistoric activities around, or on, marae. Such investigations to our knowledge have not been carried out on marae courtyards and surroundings previously.

\section{The spot-test method}

There are several phosphate-analysis methods used in archaeological investigations. The technique goes back to the well-known work of Olof Arrhenius in the 1930s (Arrhenius 1931, 1934, 1938). However, his sole interest was to map the phosphate requirements of Swedish arable land. His method used a citric-acid solution to release phosphates. After adding a reagent, the content of dissolved phosphates was recorded with a photometer in phosphate degrees $\left(\mathrm{P}^{\circ}\right)$. When doing his survey, Arrhenius soon noted that both prehistoric and medieval settlements could be identified by their higher phosphate content, and he pointed out the potential for phosphate surveys as an archaeological aid. The 'Arrhenius' method is laboratory based and time consuming. Instead, we used the so-called spot-test

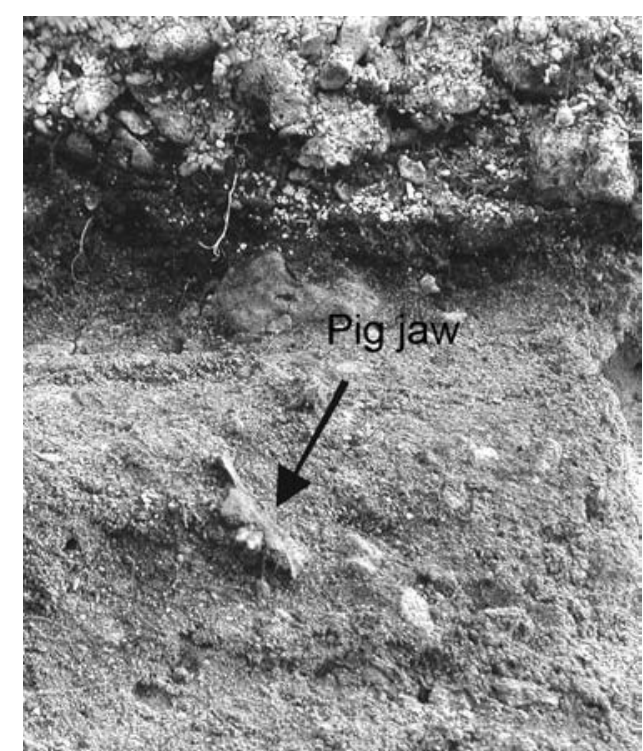

Figure 2. Detail of location of radiocarbon-dated pig jaw (photo by Paul Wallin). method that can be used in the field. The test was developed by Gundlach (1961). It has been tested extensively by the authors at Neolithic settlement sites on Gotland Island in Sweden, and has also been used at megalith graves sites in Ireland since the end of the 1970s. The method has been tested in both field and laboratory situations (Wallin 1984; I. Österholm 1989; I. Österholm and S. Österholm 1997).

The method has been proven useful for detecting or delimiting prehistoric settlements or other human activities, since phosphates that emanate from animal/human bones, fish and meat waste etc. are bound to soil particles and are very stable and insoluble in water, and are therefore ideal as indicators of prehistoric activities. An important source of phosphates is, of course, human and animal excrement, but since the marae is a ritual space, excrement is not likely to be found there, which means the phosphates detected in this investigation may derive from different sacrifices or ritual feasting (Hayden 1996:141). 


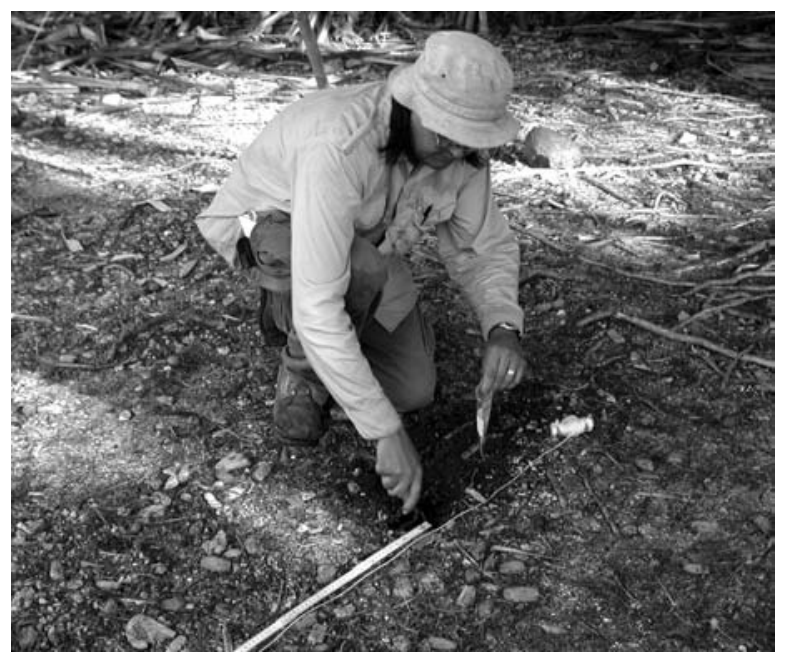

Figure 3. Systematic collection of earth samples for the phosphate analysis (photo by Reidar Solsvik).

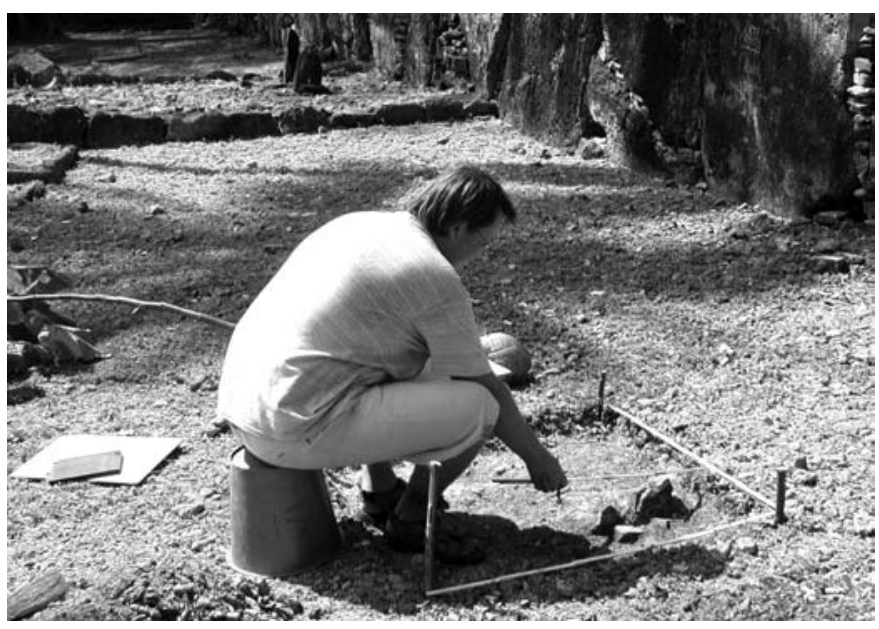

Figure 4. Earth samples collected during excavation (photo by Paul Wallin).

This is supported by finds of human and animal bones in the courtyard during our excavations. The phosphates bound in the soil can easily be released with the help of a strong acid. The principle of the spot-test method is that the phosphates in a small earth sample placed on a filter paper are extracted with the help of a strong acid and further indicated by amoniumheptamolybdate and ascorbic acid. The phosphates are indicated by a blue spot that spreads out from the earth sample, which varies in size depending on the phosphate content (Österholm and Österholm 1997:138).

Gundlach (1961) recommended the following liquids and analysis procedure:

Solution 1: $5 \mathrm{~g}$ amoniumheptamolybdate/ $\left(\mathrm{NH}_{4}\right)_{6} \mathrm{Mo}_{7} \mathrm{O}_{24} /$ is dissolved in $100 \mathrm{ml}$ cold water and mixed with $35 \mathrm{ml}$ diluted nitric acid $\left(17.5 \mathrm{ml}\right.$ conc. $\left.\mathrm{HNO}_{3}+17.5 \mathrm{ml} \mathrm{H}_{2} \mathrm{O}\right)$.

Solution 2: $0.5 \mathrm{~g}$ ascorbic acid $\left(\mathrm{C}_{6} \mathrm{H}_{8} \mathrm{O}_{6}\right)$ is dissolved in $100 \mathrm{ml}$ cold water.

Method: A pinch of soil (c. $50 \mathrm{mg}$ ) is placed on a piece of filter paper and a few drops of solution 1 are added from a drop bottle. After 30 seconds, a few drops of solution 2 are added. After a further 30 seconds, a blue spot will have radiated from the soil sample if it contains phosphates. The blueness is proportional to the degree of phosphates in the sample (Österholm and Österholm 1997:139). A graded phosphate scale (I-V) is shown in Figure 5.

When using the liquids in hot climates, as in Polynesia, it is important to keep them in a cool place, and only freshly mixed liquids should be used to obtain useful results.

The marae Manunu samples were collected from a rhombus area divided into a grid with 


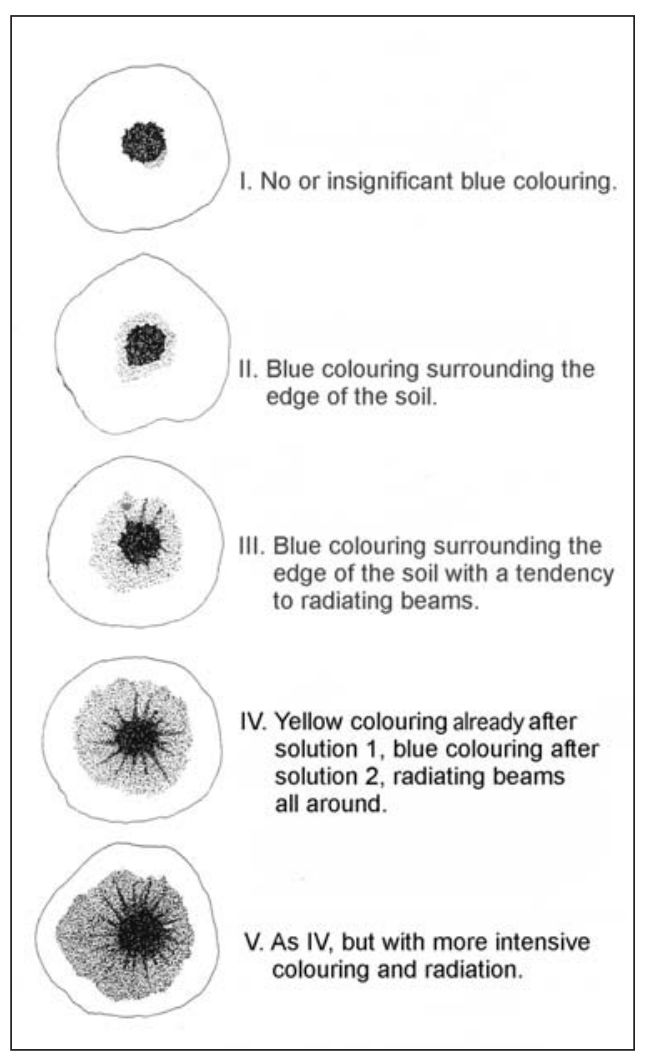

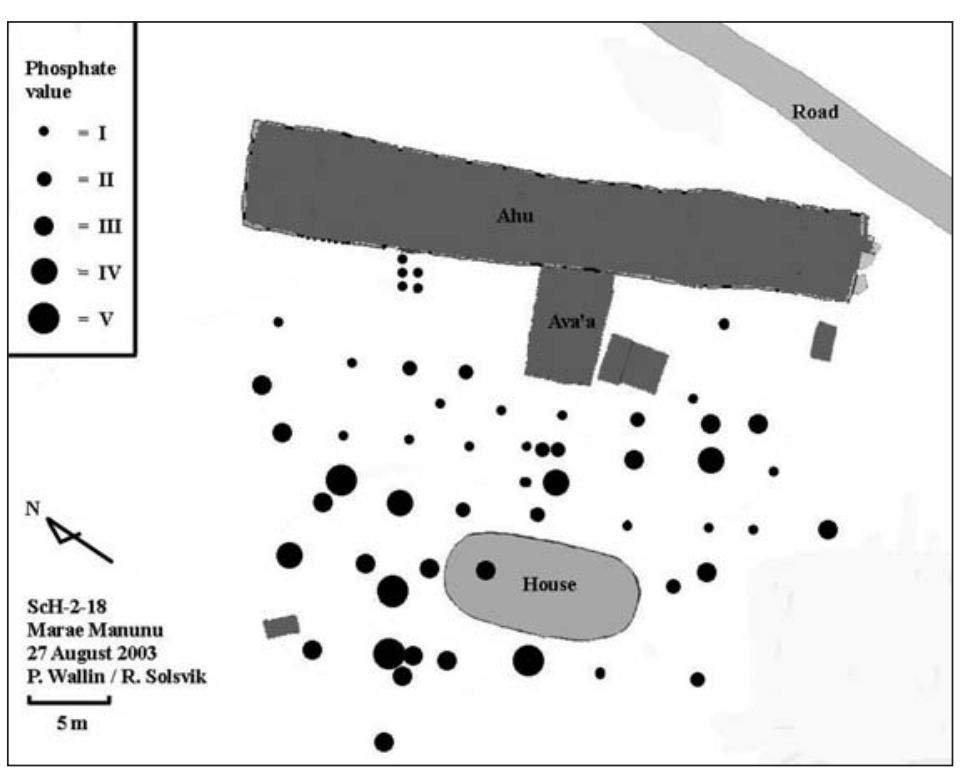

Figure 5 (left). Illustration of phosphate values (after Österholm and Österholm 1997:145).

Figure 6 (right). Results of the phosphate analysis plotted on the site plan.

$5 \mathrm{~m}$ spacing. In the areas where large-scale excavations were conducted, additional samples were collected. Samples were taken from the bottom of the cultural deposit, since phosphates are washed into the ground. Since most of the activities took place on the present surface, the sample depth was $5-10 \mathrm{~cm}$. Small holes were dug with a trowel and samples were collected in plastic bags.

\section{Phosphate analysis results}

After plotting the result of the phosphate analysis on the map, several areas containing higher phosphate levels were identified (Figure 6). Phosphate values with a range of I and II, indicate limited phosphate-generating activity. Phosphate values in the III to V range suggest phosphate production from, for example, the decomposition of human and/or animal sacrifices has taken place in the past.

In the area directly in front of the ahu and between $15 \mathrm{~m}$ and $20 \mathrm{~m}$ into the courtyard, the samples returned phosphate values in the range I and II. Hence, we can say with some confidence that no offerings, either of animals or humans, have been left to decompose in this area. Around the ahu, in a strip 5-6 m wide, white coral sand has been deposited, marking the area in front of the ahu as clean and probably tapu. The low phosphate results in this area are in accord with the evidence of use in marae architecture.

An area at the northwestern corner of the courtyard about $15 \mathrm{~m} \times 25 \mathrm{~m}$ in size and oriented in a north-south direction also stood out in the phosphate spot test, giving consistently high phosphate values of III, IV and V. This area may have had some kind of offering structure or altar. Another smaller area about $5 \mathrm{~m} \mathrm{x} 15 \mathrm{~m}$, on the southeast part of the courtyard and oriented in a northwest to southeast direction, returned medium to high phosphate values of III and IV. The phosphate values suggest there was less decomposition here than in the northwest corner of the courtyard. A few phosphate samples in other parts of the courtyard returned values 
Table 1. Osteological analysis of the bone remains, indicating MNI and NISP, at marae Manunu.

\begin{tabular}{llllll}
\hline Species & $\begin{array}{l}\text { Adult } \\
\text { (MNI) }\end{array}$ & $\begin{array}{l}\text { Juvenile } \\
\text { (MNI) }\end{array}$ & $\begin{array}{l}\text { Infant } \\
\text { (MNI) }\end{array}$ & $\begin{array}{l}\text { MNI } \\
\text { Total }\end{array}$ & NISP \\
\hline Human & 1 & 1 & 0 & 2 & 7 \\
Pig & 1 & 1 & 1 & 3 & 297 \\
Polynesian rat & 3 & 0 & 0 & 3 & 3 \\
Bird & 1 & 0 & 0 & 1 & 6 \\
Fish & 2 & 0 & 0 & 2 & 9 \\
Sheep/goat & 1 & 0 & 0 & 1 & 1 \\
Cat & 1 & 0 & 0 & 1 & 1 \\
\hline
\end{tabular}

of III-IV. An oval-shaped house on the west side of the court is also associated with the highphosphate area in the northwestern part of the marae courtyard.

\section{Bone remains}

The bones collected during excavation of the marae in 2003 were brought to the osteological research laboratory at Gotland University, Sweden. The bones were cleaned and dried in the field and packed in labelled plastic bags, and each bone was identified to species, element, side and age. Age determination of human remains was based on criteria outlined by Bass (1971). There were four individuals represented by the human remains: infant I ( $0-4$ years); infant II (5-12 years); juvenile (13-17 years) and adult (18-60 years) (Sjövold 1978).

Age determination of the animal bones followed Silver (1963). Infant animal bones were those with diaphyseal surfaces and an overall size much smaller than juvenile bones. Juvenile bones were represented by remains with incomplete and loose epiphyses. Adult individuals had fully fused epiphyses and fully erupted permanent dentition. Bone remains from human, pig, rat, bird, fish, sheep or goat and cat were identified. The NISP (number of identified specimens) and MNI for each species is shown in Table 1, and the number of bone fragments collected from excavations is shown in Figure 7.

In the western part of the courtyard, there was a relatively high frequency of pig bone, with elements from the entire skeleton recorded $\left(43\right.$ fragments $\left./ \mathrm{m}^{2}\right)$. A test unit located inside the round-ended house platform had the highest frequency of bones, with 157 fragments in a single $1 \mathrm{~m}^{2}$ unit. The remains were the most varied in terms of species, and were from pig, Polynesian rat, fish, bird, sheep/goat and cat. Human bones were also found in the excavations, but not within any of the high-phosphate areas. They were located in a trench excavated directly in front of the ahu, and in a trench in a central part of the courtyard in front of the ava'a. In these two trenches there was a low bone frequency (6-9 fragments $\left./ \mathrm{m}^{2}\right)$, including pig bone, a single bone from the Polynesian rat, and a fish bone. Pig bone was also present in the high phosphate area in the southeast part of the courtyard.

Taken together, the phosphate and the osteological analyses reveal several interesting results (Figure 7). There are three areas of the courtyard, where different activities appear to have been carried out (Figure 8). The low-phosphate area, in front of and close to the ahu, as well as on the central parts of the courtyard, also had small amounts of bone. However, this area is where the human bones were found. This might mean the area was kept relatively clean of sacrificial debris. The diverse bone remains found within the perimeter of the house may be the result of consumption of ritual meals. The area located on the western corner of the marae courtyard 


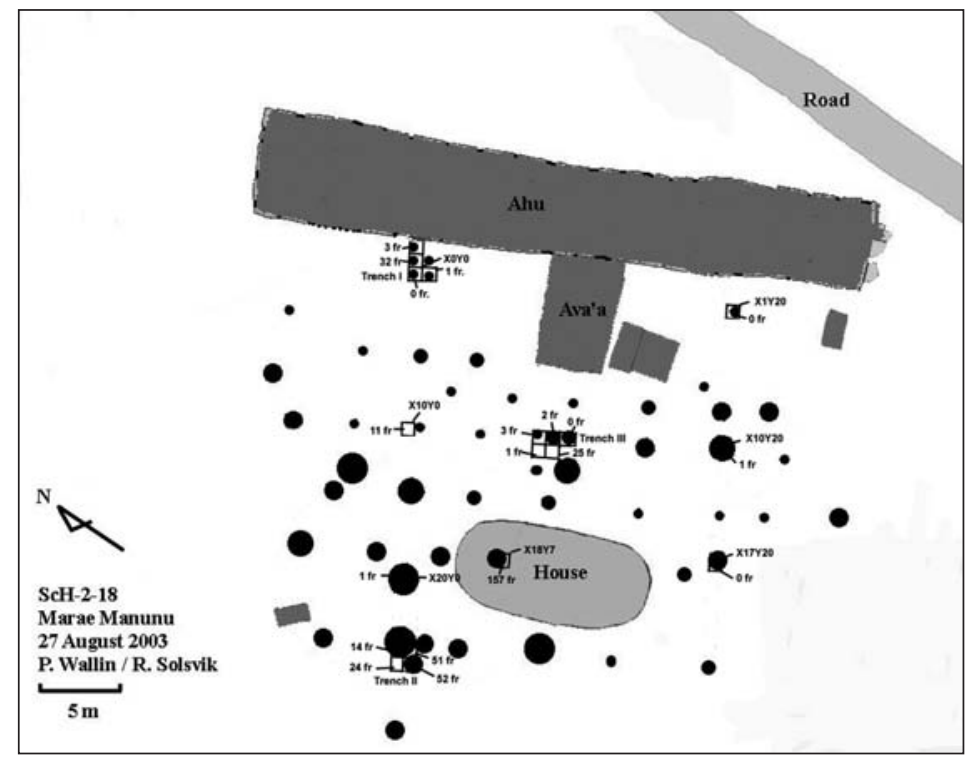

Figure 7. Excavated test pits/trenches and number of bone fragments.

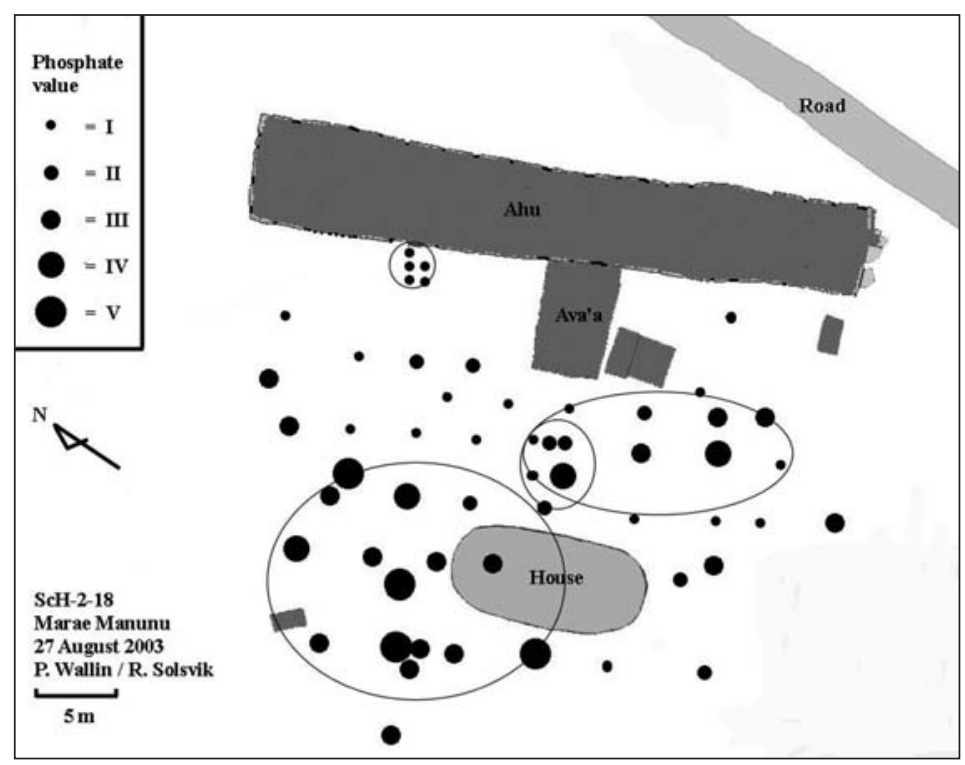

Figure 8. Interpretation of phosphate mapping.

outside the house could have been the main sacrificial area for pigs, judging by the amount of pig bone recovered. The smaller area on the southeast part of the courtyard could be a smaller sacrificial area in front of the ahu.

The western part of the courtyard is hypothesised to be the location of a large sacrificial altar. These altars, called fata (Figure 9), were an important structure at every marae. They were normally constructed of rows of wooden posts with a height of about 2-3 m, and a length of up to about $12 \mathrm{~m}$. The top of the fata platform was covered with matting. The offerings on such altars consisted of pigs, dogs, fish and fruit (Wallin 1998:12-13). When the offerings on the platform rotted, highly organic debris would drop and seep from the platform into the ground below, creating the high phosphate values. The pig bones recovered probably represent sacrifices to the gods, as well as ritual food for the persons participating in different ceremonial events. Pigs from all different age groups were present, but most bones came from small suckling pigs up to individuals six to nine months old, although some teeth indicate adult pigs were offered/ consumed (Wallin 2003).

The round-ended house in the marae courtyard is likely to be a priest house or fare ia manaha (Figure 10). The function of the fare ia manaha was to house sacred objects, such as the 

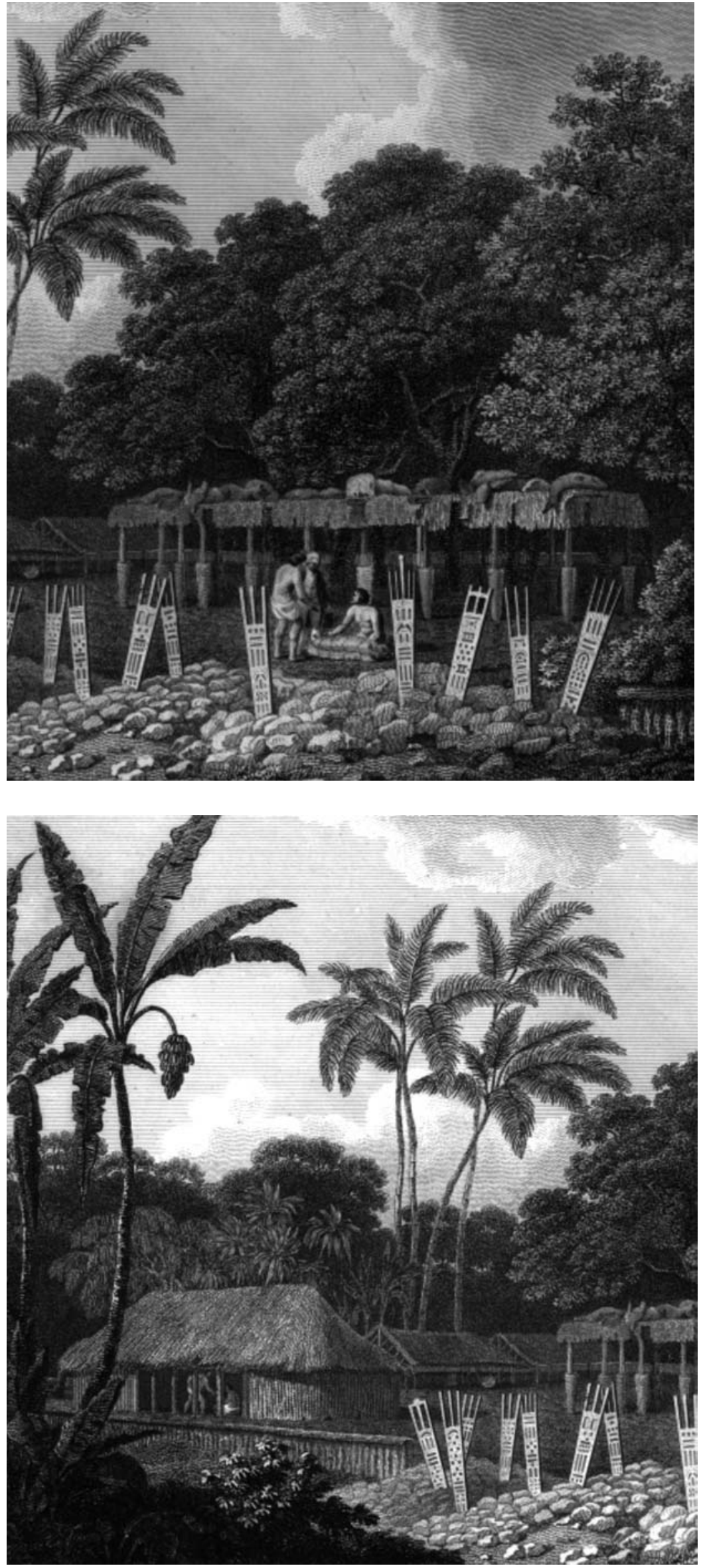

Figure 9. A fata, or offering altar, at a Tahitian marae, with pigs placed on top of the structure (detail from engraving in Wilson 1799).
Figure 10. Priest house situated in connection with a Tahitian marae (detail from Wilson 1799). 


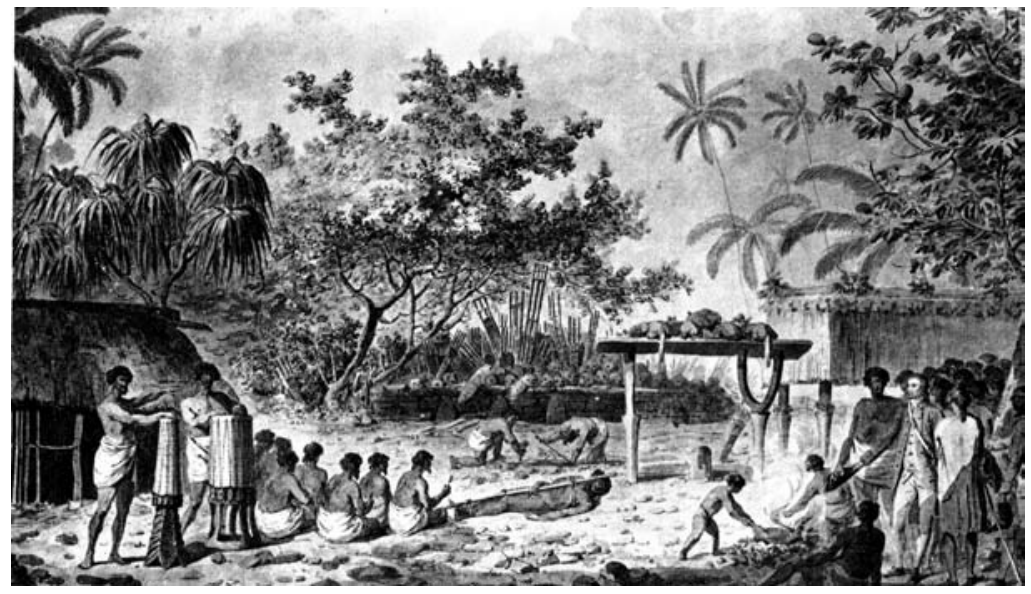

Figure 11. Human sacrifice and a smaller fata, or offering altar, recorded from Tahiti in the 1770 s (from J. Cook 1818). drums, dresses and shell trumpets used in different marae ceremonies. The house was also the place where the priests dressed and prepared themselves for ceremonial activity (Henry 1928:161-164). The sheep and cat found in the trench inside the house platform are clearly postEuropean in age. However, these remains were found under gravel and were mixed with the remains of pig, rat, bird and fish. The sheep and cat bones both came from the heads of the animals. Captain Cook gave sheep/goats and cats as gifts on his

visits to Tahiti (Ellis 1833:72), and it is feasible the bones represent European animals sacrificed at this huge marae in the late 18th century or early 19th century.

In the courtyard close to the ahu, human remains, mainly teeth, were recovered. However, phosphate samples analysed in this area were low, indicating limited decomposition had taken place at these spots. In the engraving of a human sacrifice from Tahiti made during Captain Cook's second voyage, the body is seen being treated at this location in the marae courtyard (Figure 11). In the same engraving, there are human crania visible on the ahu itself. The crania and long bones of sacrificed individuals were sometimes displayed on the marae or deposited in the ahu. It is possible the decomposition of the body took place at a special house outside the marae, and the bones were taken afterwards to the marae for display. In Figure 11, a small fata, or sacrificial altar, with pigs on it can be seen in front of the ahu. Such an altar may have been located within the southeastern area that registered high phosphate values at marae Manunu. A priest house may also be seen to the left in the picture (Figure 10).

\section{Conclusion}

The investigation of phosphate residues in prehistoric sites in tandem with a zooarchaeological analysis of bone remains demonstrates that locations with high phosphate levels also contained higher quantities of bone. Based on our initial study, it appears that a phosphate analysis carried out before excavation will be a useful tool for identifying ritual activity areas associated with Polynesian marae and ritual structures in other parts of the Pacific.

\section{Acknowledgements}

Our warmest thanks to Dr Yosi Sinoto for inviting us to collaborate with him, and for so generously sharing his knowledge on the Maeva site with us. Special thanks to all the local helpers in the field, and to the families of Maeva, who were patient with us through the years of excavating their marae. Finally, we are deeply sad to say that one of the authors of this paper, Dr. Inger Österholm, passed away before she could see the result of her last phosphate analysis in print. 


\section{References}

Arrhenius, O. 1931. Markanalysen i arkeologins tjänst. Geologiska föreningens Förhandlingar, Stockholm.

Arrhenius, O. 1934. Fosfathalten i skånska jordar. Sveriges Geologiska Undersökning. Årsbok 28. No. 3. Stockholm.

Arrhenius, O. 1938. Markundersökning och arkeologi. Fornvännen Årg. 30, Stockholm.

Arrhenius, O. 1950. Förhistoriska bebyggelser antydda genom kemisk analys. Fornvännen. Årg. 45, Stockholm.

Bass, W.M. 1971. Human Osteology: A Laboratory and Field Manual. Missouri: Special Publications Missouri Archaeological Society.

Cook, J. 1818. A Voyage to the Pacific Ocean; Undertaken by the Command of His Majesty, for making Discoveries in the Northern Hemisphere; performed under the Direction of Captains Cook, Clerke, and Gore, in the Years 1776, 1777, 1778, 1779, 1780. Compiled from the Various Accounts of that Voyage hitherto published. Volume I. Philadelphia: Robert Desilver.

Ellis, W. 1833. Polynesian researches, during a residence of nearly six years in the South Sea Islands, including descriptions of the natural history and scenery of the Islands, with remarks on the history, mythology, traditions, government, arts, manners, and customs of the inhabitants. New York: J and J. Harper.

Gundlach, H. 1961. Tüpfelmethode auf Phosphat, angewandt in prähistorischer Forschung (als Feldmethode). Mikrochimica Acta 5:735-737.

Hayden, B. 1996. Feasting in Prehistoric and Traditional Societies. In P. Wiessner and W. Schiefenhövel (eds), Food and the Status Quest. An Interdisciplinary Perspective, pp. 127-147. Providence: Berghahn Books.

Henry, T. 1928. Ancient Tahiti. Bernice P. Bishop Museum Bulletin 48, Honolulu: Bishop Museum Press.

Österholm, I. 1989. Bosättningsmönstret på Gotland under stenåldern. En analys av fysisk miljö, ekonomi och social struktur. Theses and Papers in Archaeology 3. Department of Archaeology, Stockholm University.

Österholm, I. and S. Österholm 1982. Spot test som metod för fosfatanalys i fält-praktiska erfarenheter. Riksantikvarieämbetets Gotlandsundersökningar $\mathrm{Nr} 6$.

Österholm, I. and S. Österholm 1997. Spot tests as a phosphate survey method in the field: practical experiences. In G. Burenhult (ed), Remote sensing Vol. 1. Theses and Papers in North-European Archaeology 13:a 137-152.

Silver, I.A. 1963. The Ageing of Domestic Animals. In D. Brothwell and E. Higgs (eds), Science in Archaeology, pp. 250-268. London: Thames and Hudson.

Sinoto, Y.H. 1996. Mata'ire'a Hill, Huahine. A Unique Settlement, and a Hypothetical Sequence of Marae Development in the Society Islands. In J. Davidson, G. Irwin, B.F. Leach, A. Pawley, and D. Brown (eds), Oceanic Culture History Essays in Honour of Roger C. Green, pp. 541-553. New Zealand Journal of Archaeology Special Publication. Dunedin, New Zealand Journal of Archaeology.

Sinoto, Y.H. 2002. A Case Study of Marae Restorations in the Society Islands. In C.M. Stevenson, G. Lee, and FJ. Morin (eds), Pacific 2000. Proceedings of the Fifth International Conference on Easter Island and the Pacific, pp. 253-265. Los Osos: Easter Island Foundation.

Sjövold, T. 1978. Inference Concerning the Age Distribution of Skeletal Population and some Consequences for Paleodemography. Anthropologie Kozlemenyek 22:99-114.

Wallin, P. 1984. Den gropkeramiska boplatsen Hemmor i När socken på Gotland. En studie av topografi, resursområde och fyndmaterial. Uppsats i påbyggnadskurs i arkeologi vid, unpublished BA Thesis, Stockholms Universitet.

Wallin, P. 1998. The Symbolism of Polynesian Temple Rituals. Kon-Tiki Museum Occasional Papers, Volume 4. Oslo: Kon-Tiki Museum. 
Wallin, P. 2003. Osteological Analysis of Bone Remains from marae Manunu and Marae Matairea Rahi. Unpublished report in possession of the authors.

Wallin, P., E. Komori and R. Solsvik 2004. Excavations of One Habitation Site and Various Marae Structures on Land Fareroi, Te Ana, Tehu'a, Tearanu'u, and Tetuatiare, in Maeva, Huahine, Society Islands, French Polynesia, 2003. Report from the Project 'Local Developments - Regional Interactions' to the Service de la Culture et du Patrimoine, Punaauia, Tahiti. Unpublished report in the Archives of the Institute for Pacific Archaeology and Cultural History, Oslo.

Wallin, P. and R. Solsvik 2005a. Historical Records and Archaeological Excavations of Two 'National' Marae Complexes on Huahine, Society Islands, French Polynesia: A Preliminary Report. Rapa Nui Journal 19(1):13-24.

Wallin, P. and R. Solsvik 2005b. Radiocarbon Dates from Marae Structures in the District of Maeva, Huahine, Society Islands, French Polynesia. Journal of the Polynesian Society 114(4):375-383.

Wallin, P. and R. Solsvik 2006a. Dating Ritual Structures in Maeva, Huahine. Assessing the development of marae structures in the Leeward Society Islands, French Polynesia. Rapa Nui Journal 20(1):9-30.

Wallin, P. and R. Solsvik 2006b. Report from Archaeological Investigations of Marae Structures in the District of Maeva, Huahine, 2003. In H. Marchesi (ed), Bilan de la recherche archéologique en Polynésie francaise 2003-2004. Dossier d'Archéologie polynésienne, Vol. 3. Punaauia: Ministère de la Culture de Polynésie francaise, Service de la Culture et du Patrimoine.

Wilson, J. 1799. A Missionary Voyage to the South Pacific Ocean, Performed on the Years 1796, 1797, 1798, on the Ship Duff, Commanded by Captain James Wilson Under the Direction of the Missionary Society. London: T. Chapman. 